\title{
Yüksek Fırın Cürufu ile Stabilize Edilmiş Killi Bir Zeminin Rijit Kaplama Kalınlığı ve Maliyetine Etkileri
}

\author{
Tacettin Geçkil ${ }^{1}$, Mehmet Mahmut Tanyıldız ${ }^{2 *}$, Ceren Beyza İnce ${ }^{3}$, Ekrem Serdar Yıldıran ${ }^{4}$ \\ 1* İnönü Üniversitesi, İnşaat Mühendisliği, İnşaat Mühendisliği Bölümü, Malatya, Türkiye, (ORCID: 0000-0001-8070-6836), tacettin.geckil@inonu.edu.tr \\ 2* İnönü Üniversitesi, İnşaat Mühendisliği, İnşaat Mühendisliği Bölümü, Malatya, Türkiye, (ORCID: 0000-0001-5992-2665), mmtanyildizi@hotmail.com \\ 3 İnönü Üniversitesi, İnşaat Mühendisliği, İnşaat Mühendisliği Bölümü, Malatya, Türkiye, (ORCID: 0000-0002-6385-0964), c.beyzaince@gmail.com \\ 4 Togi Metal İnş. San. Tic. Ltd. Şti., Malatya, Türkiye, (ORCID: 0000-0002-8678-5544)
}

(İlk Geliş Tarihi 5 Mayıs 2021 ve Kabul Tarihi 7 Ağustos 2021)

(DOI: 10.31590 /ejosat.932204)

ATIF/REFERENCE: Geçkil, T., Tanyıldız, M. M., İnce, C. B. \& Yıldıran, E. S. (2021). Yüksek Fırın Cürufu ile Stabilize Edilmiş Killi Bir Zeminin Rijit Kaplama Kalınlığı ve Maliyetine Etkileri. European Journal of Science and Technology, (27), 158-170.

Öz

Günümüzde önemli çevre sorunlarına neden olan kömür kaynaklı atık yüksek fırın cürufunun (YFC) inşaat sektöründe, özellikle şehir içi yollarda, havaalanı pistlerinde, otopark sahalarında, terminallerde ve beton üretiminde puzolan malzeme olarak kullanılması ve bertaraf edilmesi konusu son zamanlarda önemli bir hale gelmiştir. Bu çalışmada, atık YFC ile stabilize edilmiş taşıma gücü zayıf killi bir zeminin rijit yol üstyapı kaplama kalınlığı ve maliyetine etkileri araştırılmıştır. Bu amaçla kil zemine ağırlıkça \%0, 5, 10, 15 ve 20 oranlarında atık YFC ilave edilerek stabilize karışım numuneleri hazırlanmıştır. Saf ve stabilize numuneler standart proktor, serbest basınç ve kaliforniya taşıma oranı (CBR) deneylerine tabi tutularak fiziksel ve mekanik özellikleri belirlenmiş̧ir. Deneyler neticesinde, en yüksek dayanımın elde edildiği stabilize karışım numunesinin YFC oranı (\%20 YFC) tespit edilmiştir. Bu oran dikkate alınarak, AASHTO 1993 yöntemi ile saf ve YFC katkılı kil zemin üzerine inşa edilecek rijit üstyapı tabaka kalınlıkları ve maliyetlerinin hesabı yapılmıştır. Çalışmada, saf ve \%20 YFC katkılı killi zeminler için kaplama kalınlıkları ve maliyetleri karşılaştırılarak, beton yol kaplamalarının ekonomik değerlendirmesi yapılmıştır. Bu amaçla çalışmada, farklı eşdeğer tek dingil yük tekerrür sayıları (proje trafiği, $\left.\mathrm{W}_{8,2}\right), 75 \times 10^{6}, 100 \times 10^{6}, 125 \times 10^{6}$ ve $150 \times 10^{6}$ alınarak saf kil zemin için rijit üstyapı kalınlıkları sırasıyla $31,90 \mathrm{~cm}, 33,35 \mathrm{~cm}, 34,54 \mathrm{~cm}$ ve $35,53 \mathrm{~cm}$; \%20 YFC katkılı killi zemin için ise sırasıyla $28,83 \mathrm{~cm}, 30,38 \mathrm{~cm}, 31,55 \mathrm{~cm}$ ve $32,56 \mathrm{~cm}$ olarak belirlenmiştir. Kabul edilen trafik değerleri için elde edilen bu kalınlıklara göre $1000 \mathrm{~m}$ uzunluğunda ve $20 \mathrm{~m}$ genişliğindeki bir yolun \%20 YFC katkılı killi zemin için rijit üstyapı maliyetinin saf killi zemine kıyasla sırasıyla $\% 9,63, \% 8,91, \% 8,68$ ve $\% 8,36$ daha ekonomik olduğu tespit edilmiştir.

Anahtar Kelimeler: Kil zemin, yüksek firın cürufu (YFC), zemin stabilizasyonu, rijit üstyapı, AASHTO metodu

\section{Effects of a Clayey Soil Stabilized with Blast Furnace Slag on Rigid Pavement Thickness and Cost}

\begin{abstract}
The use and disposal of coal-sourced blast furnace slag (BFS), which causes significant environmental problems today, as a pozzolan material in the construction industry, especially in urban roads, airport runways, parking lots, terminals and concrete production, has recently become important. In this study, the effects of a clay-bearing soil stabilized with waste BFS on rigid road pavement covering thickness and cost were investigated. For this purpose, stabilized mixture samples were prepared by adding $0,5,10,15$ and $20 \%$ waste BFS to the clay soil. Pure and stabilized samples were subjected to standard proctor, unconfined compression and california bearing ratio (CBR) tests to determine their physical and mechanical properties. As a result of the experiments, the BFS ratio (20\% BFS) of the stabilized mixture sample with the highest strength was determined. Taking into account his ratio, the thickness and costs of the rigid pavement layer to be constructed on pure and BFS-added clay soil were calculated with the AASHTO 1993 method. In the study, the economical evaluation of concrete road pavements was made by comparing the pavement thickness and cost for the pure and the clay soils with $20 \%$ BFS. In the study, different equivalent single axle load repetition numbers (project traffic, $\mathrm{W}_{8,2}$ ), $75 \times 10^{6}, 100 \times 10^{6}$, $125 \times 10^{6}$ and $150 \times 10^{6}$, rigid pavement thicknesses for pure clay soil $31.90 \mathrm{~cm}, 33.35 \mathrm{~cm}, 34.54 \mathrm{~cm}$ and $35.53 \mathrm{~cm}$ respectively; for clayey soils with $20 \%$ BFS added, it was determined as $28.83 \mathrm{~cm}, 30.38 \mathrm{~cm}, 31.55 \mathrm{~cm}$ and $32.56 \mathrm{~cm}$ respectively. According to these thicknesses obtained for the accepted traffic values, compared to the pure clay soil of the rigid pavement cost for $20 \%$ BFS additive clay soil of a $1000 \mathrm{~m}$ long and $20 \mathrm{~m}$ wide road. 9,63\%, 8,91\%, 8,68\% and 8,36\%, respectively, have been found to be more economical.
\end{abstract}

Keywords: Clay soil, blast furnace slag (BFS), soil stabilization, rigid pavement, AASHTO method. 


\section{Giriş}

Karayolu üstyapıları, çeşitli trafik yüklerine ve çevresel koşullara maruz kalan alttemel, temel ve kaplama gibi tabakalarından oluşan tabakalı yapılardır. Üstyapılar, trafik yükleri ve çevresel koşulların etkisi altında gösterdikleri davranış ve oluşturuldukları malzemeye bağlı olarak esnek ve rijit üstyapılar olmak üzere iki ana gruba ayrılırlar. Kaplama inşasında bağlayıcı olarak asfalt kullanılan yapılar esnek, portland çimentosu kullanılan yapılara ise rijit (beton) yol olarak adlandırılmaktadır (Tunç, 2001). Beton yollarda, trafik yüklerini daha geniş bir alana yayarak tabana iletmek, tabanda ve kaplama üzerinde deformasyon oluşmasını engellemek kaplamanın görevidir (Karayolları Beton Yol Üstyapılar Projelendirme Rehberi, 2019).

Beton yollar, genel olarak üstyapı taban zemini üzerine inşa edilen portland çimentolu beton plaktan ve üstyapı tabanı ile beton kaplama arasına yerleştirilen temel/alttemel/seçme malzeme tabakalarından oluşturulmaktadır. Standart dingil yükü sayısı (proje trafiği) $60-75 \times 10^{6}$ dan fazla olan veya tek yöndeki günlük ticari taşıt sayısı 5.000'den fazla olan yollarda beton kaplama yapılması öngörülmektedir. Proje trafiği yüksek bu rijit üstyapıların tasarımında ki amaç; baz alınan hizmet (tasarım) ömrü süresince kaplama üzerinden geçecek trafiği, güvenli bir şekilde taşırken büyük deformasyonlara maruz kalmayacak şekilde beton plak kalınlığının hesap edilmesi ve üstyapıda kullanılacak malzemelerin özelliklerinin belirlenmesidir (Karayolları beton yol üstyapılar projelendirme rehberi, 2019; Bayrak, 2007).

Günümüzde, karayolu beton yol üstyapılarının inşa edileceği bölgelerde, yoğun trafik yükü altında çatlama ve deformasyon gösterebilecek taşıma gücü zayıf taban zeminlerine muhtelif katkı maddeleri ilave edilerek zeminlerin mukavemeti artırılmakta ve üstyapının taşıma gücü sağlam bir taban zeminin üzerine oturması sağlanmaktadır. $\mathrm{Bu}$ maksatla, zayıf taşıma gücüne sahip zeminlerin dayanımlarını arttırmak için fiziksel, mekanik ve kimyasal olmak üzere birçok yöntem kullanılarak zeminlerin dayanımları arttırılmaya çalışılmaktadır (Tunç, 2001). Bu amaçla genellikle tercih edilen yöntem, zemine katkı maddesi ilave edilerek dayanımında iyileşme sağlamaktır. Bu amaçla çimento, uçucu kül, kireç, YFC vb. gibi katkılar, zeminlerin dayanımlarının iyileştirilmesinde kullanılan başlıca katkı maddeleridir. Bu katkı maddelerinin kullanılması ile zeminlerin durabilite, permeabilite, stabilite ve sıkışabilirlik gibi özelliklerinde iyileşme sağlanabildiği görülmüştür. Ayrıca, bu katkı maddelerinin maliyetlerinin uygun olması ve kolaylıkla temin edilebilmesi, zemin iyileştirilmesinde veya stabilizasyonunda kullanılmasını tercih sebebi haline getirmiştir (Çakılcıoğlu, 2007; Hausman, 1990; Kılıç, 2008). Karayolu rijit üstyap1 yol yapım çalışmalarında; yağışlar, yeraltı suyu vb. gibi nedenlerle şişme, ıslanma ile çökme davranışı (hidro-sıkışma) gösteren ve sıvılaşma potansiyeli yüksek killi zeminler, çeşitli atık katkı maddeleri kullanılarak stabilize edilmekte ve taşıma gücü yüksek zeminler elde edilmektedir (Emery, Kim ve Cotsworth 1976).

Günümüzde gelişen teknoloji ile artan nüfusun bir neticesi olarak ortaya çıkan atıkların bertarafında karşılaşılan problemler göz ardı edilemeyecek boyutlara ulaşmıştır. Bu nedenle, sanayi atıklarının bertarafı oldukça önem kazanmıştır. Bu amaçla, zemin iyileştirme ve dolgu malzemesi gibi farklı inşaat mühendisliği uygulamalarında çeşitli atık malzemelerin kullanımı oldukça yaygınlaşmıştır. $\mathrm{Bu}$ sayede, çevresel kirliliğe neden olan atık malzemelerin yeniden kullanım ve geri dönüşümü sağlanmış olacağı gibi, ekonomi ve enerjiden de kazanç elde edilecektir (Huang, 2017; Gökalp, 2018; Gurer, Akbulut ve Kurklu 2004; Aruntaş, 2006; Kodikara, Yeo 2005).

Bu çalışmada, atık YFC kullanılarak stabilize edilmiş killi bir zeminin fiziksel ve mekanik özellikleri belirlenerek daha önce literatürde çalışılmamış olan rijit yol üstyapı kalınlık ve maliyetine etkileri araştırılmıştır.

Demir-çelik üretimi sırasında bir yan ürün olarak ortaya çıkan YFC, karayolu mühendisliğinde yol kaplaması, alttemel, temel, zemin iyileştirme ve dolgu malzemesi gibi çeşitli mühendislik uygulamalarında kullanılmaktadır. YFC'nin yapıs1 \%95'i silika, kalsiyum, alüminyum, magnezyum ve oksijen gibi elementlerden oluşmaktadır (Yılmaz, 2013; Tokyay, Erdoğdu, 2002; ACI, 2005). Bu özelliklere sahip bir yan ürün olarak elde edilen YFC'nin, zayıf zeminlerin dayanımlarının artırılması maksadıyla kullanılması, hem zeminin taşıma gücü, hem atıkların bertaraf edilmesi ve hem de ekonomik kazanç bakımından fayda sağlayacağı düşünülmektedir (ACI, 2005).

Günümüzde, YFC kullanılarak yapılan zemin iyileştirme çalışmalarında olumlu sonuçlar elde edilmiştir. Yapılan çalışmalarda, YFC'nin kil zeminde şişmeye neden olan yeraltı suyundan etkilenmediği, yol taban zemininde ve yol stabilizasyonunda katkı malzemesi olarak kullanılabileceği görülmüştür (Kuloğlu, Özden ve Kayalar, 2006). YFC katkısının zeminlerin mekanik, fiziksel ve dayanım özelliklerinin iyileştirilmesi üzerine yapılan çalışmaların sonucunda, cüruf katkısının artışıyla killi zeminlerin CBR değerlerinin de arttığ görülmüştür (Kavak ve Bilgen, 2005). Kil zemin içerisine \%5, 10 , 20,30 ve 50 oranlarında YFC karıştırılarak hazırlanmış stabilize karışım numunelerinde, saf kil zemin içindeki YFC oranı arttıkça birim hacim ağırlığının da artış gösterdiği, plastisite indeksinin azaldığı ve zemin dayanımının arttığı tespit edilmiştir (Sivrikaya, Yavascan ve Cecen, 2014). Killi zeminlerin dayanımlarını arttırmak amacıyla kireç ve YFC'nin birlikte kullanıldığı bir çalışmanın deney sonuçlarına göre, YFC'nin tek başına plastisite üzerinde bir etkisinin olmadığı, ancak \%5 kireç ve \%3,33 YFC karışımında plastisitenin 28'den 9'a düştüğü görülmüştür. Ayrıca, YFC'nin tek başına kullanıldığında serbest basınç dayanımını yaklaşık 2 kat arttırırken, bu oranlarda birlikte kullanıldığında ise 11 kat arttırdığı tespit edilmiştir (Bilgen, Kavak ve Yıldırım, 2010). Şişme özelliği gösteren kil zeminlerin dayanımlarının iyileştirilmesi maksadıyla YFC ve çimento kullanılan bir çalışmada, en efektif olan $\% 15$ YFC- $\% 5$ çimento oranının, kil zeminlerin plastisite indeksini ve şişme yüzdesini önemli ölçüde azalttığı görülmüştür (Cokca, Yazıc1 ve Özaydin, 2009).

$\mathrm{Bu}$ çalışmada, daha önce yapılan çalışmalardan farklı olarak, atık YFC ile dayanımı artırılan taşıma gücü zayıf killi bir yol taban zemininin, rijit yol kaplama kalınlığına ve maliyetine etkileri araştırılmıştır. Bu amaçla, dayanımları artırılmış zemin numuneleri üzerinde sıkıştırma, serbest basınç, CBR deneyleri yapılmış ve AASHTO 1993 tasarım yöntemi yardımıyla saf kil ve YFC katkılı zeminler için rijit kaplama kalınlıkları belirlenerek güncel maliyetleri hesaplanmıştır.

\section{Materyal ve Deneysel Yöntem}

\subsection{Materyal Ve Numune Hazırlama}

Deneysel çalışmada, yol taban zemini olarak kullanılan kil zemin Malatya Kiltepe bölgesinden temin edilmiştir. Kil zemin üzerinde elek analizi (ASTM C136/C136M), hidrometre (ASTM 
D422-63), modifiye kompaksiyon (ASTM 1557) ve Atterberg limitleri (ASTM 4318) deneyleri yapılmıştır. Zeminin deneylerden elde edilen mühendislik özellikleri Çizelge 1'de özetlenmiştir. Zemininin gradasyon eğrisi ise Şekil 1'de verilmiştir. Zemin sınıfı, Birleştirilmiş Zemin Sınıflandırma Sistemi (USCS) verilerine göre yüksek plastisiteli kil $(\mathrm{CH})$ olarak tespit ediliştir (Çizelge 1).

Çizelge 1. Kil Zeminin Mühendislik Özellikleri

\begin{tabular}{ll}
\hline Özellik & Değer \\
\hline Dane birim hacim ağırlığı, $\gamma \mathrm{s},\left(\mathrm{g} / \mathrm{cm}^{3}\right)$ & 2,680 \\
Maksimum kuru birim hacim ağırlığı, $\gamma_{\mathrm{kmax}},\left(\mathrm{g} / \mathrm{cm}^{3}\right)$ & 1,450 \\
Optimum su içeriği, $\mathrm{w}_{\mathrm{opt}},(\%)$ & 27 \\
Likit limit, (LL), $\%)$ & 61 \\
Plastik limit, (PL), (\%) & 29 \\
Plastisite indeksi, (PI), (\%) & 32 \\
Sinıflandırma, (USCS'ye göre) & $\mathrm{CH}$ \\
\hline
\end{tabular}

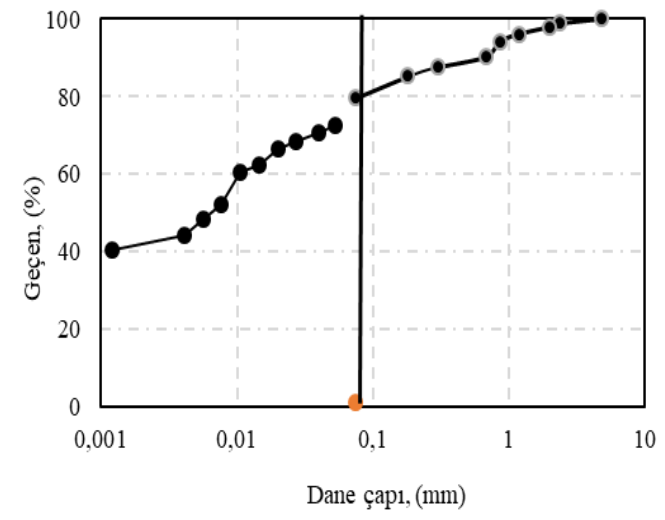

Şekil 1. Kil Zeminin Dane Çapı Dağılımı Eğrisi

Kil zeminin dayanımının iyileştirilmesi amacıyla kullanılan ve özgül ağırlığ $12,75 \mathrm{~g} / \mathrm{cm}^{3}$ olan YFC, Karabük ili Karçimsa tesisinden temin edilmiş ve kimyasal özellikleri Çizelge 2'de gösterilmiştir.

Çizelge 2. Yüksek Fırın Cürufunun (YFC) Kimyasal Özellikleri

\begin{tabular}{lcccccccccccc}
\hline Kimyasal Bileşen & $\mathrm{SiO}_{2}$ & $\mathrm{Al}_{2} \mathrm{O}_{3}$ & $\mathrm{Fe}_{2} \mathrm{O}_{3}$ & $\mathrm{CaO}$ & $\mathrm{MgO}$ & $\mathrm{SO}_{3}$ & $\mathrm{~S}$ & $\mathrm{Na}_{2} \mathrm{O}$ & $\mathrm{K}_{2} \mathrm{O}$ & $\mathrm{TiO}_{2}$ & $\mathrm{Mn}_{2} \mathrm{O}_{3}$ & $\mathrm{CI}$ \\
Ağırlıkça İçerik, (\%) & 32,47 & 9,94 & 1,25 & 32,45 & 9,31 & 0,82 & 0,33 & 0,31 & 0,85 & 1,16 & 3,51 & 0,015 \\
\hline
\end{tabular}

Deneysel çalışmalar kapsamında, kil-YFC karışım numuneleri hazırlanmadan önce ilk olarak, her iki malzeme 24 saat boyunca $105 \pm 5{ }^{\circ} \mathrm{C}^{\prime}$ lik etüvde kurutulma işlemine tabi tutulmuştur. İkinci aşamada, kil zemin içerisine daha önceden yapılmış diğer çalışmalar (Kavak ve Bilgen; 2005) dikkate alınarak ağırlıkça \%0, 5, 10, 15 ve 20 miktarlarında YFC ilave edilerek stabilize karışım numuneleri hazırlanmıştır.

Çalışma kapsamında hazırlanan saf kil ve stabilize karışım numuneleri sirasiyla Kil, \%5YFC, \%10YFC, \%15YFC ve $\% 20$ YFC olarak adlandırılmıştır.

\subsection{KIvam Limitleri Deneyi}

Kıvam limitleri, ince daneli zeminleri içerdikleri su muhtevasına bağlı olarak tanımlamada kullanılan çok önemli parametrelerden biridir ve TS 1900-1'e uygun olarak belirlenmektedir. İnce daneli zeminlerin birçok özelliği kıvam limitlerine bağlı olarak ifade edilmektedir. Siltler ve killer bünyelerine su alan ve aldıkları su miktarına göre kıvamları değişebilen ince daneli zemin grubu malzemelerdir. Likit limit durumu, mevcut zeminin plastik durumdan, akıcı bir duruma geçtiği andaki su muhtevasıdır. İnce taneli zeminlerde kırılmadan şekil verilebilme özelliğine plastiklik ismi verilmektedir. Islak zemin, su ile yoğrulup bu sırada zeminin yüzeyinde çatlaklar oluşturulursa, bu çatlakların oluştuğu andaki su muhtevası plastik limit olarak tanımlanmaktadır (Bilgen, 2007).

\subsection{Standart Proctor Deneyi}

Deney, zeminlerin taşıma kapasitesini artırmak, permeabilitesini ve farklı yükler altındaki oturmalarını en aza indirgemek amaciyla, zemin numunesindeki havanın, su ve mekanik araçlar yardımıyla dışarı atılarak maksimum kuru birim hacim ağırlığının $\left(\rho_{\mathrm{k}}\right)$ ve optimum su muhtevasının $\left(\mathrm{w}_{\mathrm{opt}}\right)$ belirlenmesi esasına dayanmaktadır. TS 1900-1 standardına göre yapilan deneyde, zemin numunesi $105^{\circ} \mathrm{C}^{\prime} \mathrm{de} 24$ saat kurutulduktan sonra belirli oranlarda su eklenerek yoğrulur ve üçer kademe halinde kalıba yerleştirildikten sonra her seferinde $2,5 \mathrm{~kg}$ ağırlığındaki tokmak ile $25 \mathrm{kez}$ vurularak sıkıştırılır.
Numunelerin farklı su içeriklerindeki kuru birim ağırlık değerlerine göre doygunluk eğrisi çizilerek, maksimum kuru birim ağırlığı ve optimum su muhtevası değerleri belirlenir (Yılmaz, Yıldıran ve Keskin 2017).

Bir zeminin kompaksiyon derecesi veya ölçüsü, sıkıştırılmış zemine ait kuru yoğunluk $\left(\rho_{\mathrm{k}}\right)$ değeri ile belirlenmektedir. Sıkışmış zeminde $\left(\rho_{\mathrm{k}}\right)$ değerinin en yüksek olduğu durumdaki su içeriği, o zeminin optimum su içeriği $\left(\mathrm{W}_{\text {opt }}\right)$ olarak adlandırılır (Bilge, 2011).

\subsection{Tek Eksenli Serbest Basınç (UCS) Deneyi}

TS 1900-2 standardına göre UCS deneyi, kohezyonlu zeminlerin kayma mukavemetinin belirlenmesi amacıyla yapılan bir deneydir. Deneyde, etüvde $105^{\circ} \mathrm{C}^{\prime}$ de 24 saat kurutulan zemin numunesi, daha önce belirlenen optimum orandaki su ile yoğrulur ve serbest basınç kabına 4 tabaka halinde serilir. Her tabakadan sonra tokmak ile $10 \mathrm{kez}$ vurulup sıkıştırılan numune, kalıptan çıkarılarak planlanan kür süresi boyunca oda sıcaklığında muhafaza edilir. Deneye tabi tutulan numunede oluşan deformasyon ve şekil değiştirmeler esas alınarak zeminin dayanım değerleri tespit edilir (Yılmaz, Yıldıran ve Keskin 2017).

\subsection{CBR Deneyi}

CBR deneyi TS 1900-2 standardına göre, en kesit alanı 1935 $\mathrm{mm}^{2}$ olan bir pistonun belirli bir hızda $(1,27 \mathrm{~mm} /$ dakika $)$ zemin içine baskı uygulaması ile bulunan yük-penetrasyon bağlantısı vasıtasıyla zeminin taşıma gücünün belirlenmesine yardımcı olan bir deneydir. CBR değeri, zeminlerin $2,5 \mathrm{~mm}$ ve $5,0 \mathrm{~mm}$ deplasman veya çökme değerlerine karşılık gelen yük değerleri için hesaplanmaktadır. Hesaplanan değerlerden yüksek olanı zeminin taşıma oranı değeri olarak kabul edilmektedir. Deneyde, etüvde $105^{\circ} \mathrm{C}^{\prime}$ de 24 saat kurutulan numune optimum su ilave edilerek yoğrulur ve CBR kalıbına 3 kademede serilir. Her kademeden sonra $2,5 \mathrm{~kg}$ ağırlığındaki tokmak ile $56 \mathrm{kez}$ vurulup sıkıştırılan numune planlanan kür süresinden sonra deneye tabi tutulur. Deney sonucunda 2,5 $\mathrm{mm}$ ve $5 \mathrm{~mm}$ penetrasyon için CBR değerleri belirlenir (Yılmaz, Y1ldıran ve Keskin 2017). 


\subsection{AASHTO 1993 Yöntemi ile Rijit Üstyapı Tasarımı}

Karayolu rijit üstyapı tasarımında hedef, projelendirilen tasarım ömrü süresince, tekerrür edecek olan trafiği, çatlamalara ve deformasyonlara maruz birakmadan emniyetli bir düzeyde taşıyabilmek için yol üstyapı tabaka kalınlıklarının belirlenmesi ve bu tabakaları olușturacak malzeme özelliklerinin saptanmasıdır. Bu kapsamda, beton kaplamanın performansı için 8,2 tonluk standart eşdeğer tek dingil yükü tekerrür sayısının $\left(\mathrm{W}_{8,2}\right)$, kaplamanın performansı üzerindeki etkisi göz önünde bulundurularak elde edilen AASHTO 1993 denklemi Eşitlik 1'de verilmiştir. Beton kaplama kalınlığı (d), Eşitlikte verilen formüle göre hesaplanmaktadır (AASHTO, 1993).

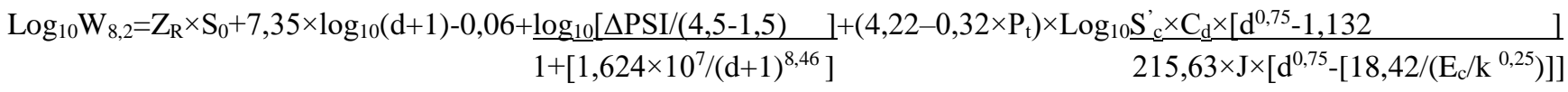

Bu eşitlikte;

$\mathrm{W}_{8,2}$ : Toplam standart dingil yükü tekerrür sayısı (8,2 ton)

$\mathrm{Z}_{\mathrm{R}} \quad$ : Standart normal sapma

$\mathrm{S}_{\mathrm{o}} \quad$ : Toplam standart sapma

d : Kaplamanın plak kalınlığı (inç) $(0,0254 \mathrm{~m})$

$\Delta$ PSI : İlk tasarım servis yeteneği $\left(\mathrm{p}_{\mathrm{o}}\right)$ ile son servis yeteneği indeksi $\left(\mathrm{p}_{\mathrm{t}}\right)$ arasındaki fark

$\mathrm{S}_{\mathrm{c}}^{\prime} \quad$ : Beton için kopma modülü (psi) $\left(6,8950 \times 10^{3} \mathrm{~Pa}\right)$

J : Yük transfer katsayısı

$\mathrm{C}_{\mathrm{d}} \quad$ : Yol drenaj katsayisı

$\mathrm{E}_{\mathrm{c}} \quad$ : Beton için elastisite modülü (psi) $\left(6,8950 \times 10^{3} \mathrm{~Pa}\right)$

$\mathrm{k}$ : Taban reaksiyon modülü (pci) $\left(27679,9 \mathrm{~kg} / \mathrm{m}^{3}\right)$ göstermektedir.

\subsubsection{Servis yeteneği (performans ölçütü)}

Yol mühendisliğinde kaplamanın performans ölçütü olarak kabul edilen servis yeteneği değeri 0-5 aralığında değerlendirilmektedir. Sıfır (0) en düşük beş (5) en yüksek performans ölçütü derecesini belirtir. Başlangıç performans ölçütü indeksi $\left(\mathrm{p}_{\mathrm{o}}\right)$, son performans ölçütü indeksi $\left(\mathrm{p}_{\mathrm{t}}\right)$ olarak gösterilir ve $\left(\mathrm{p}_{\mathrm{o}}\right)$ değeri zaman içerisinde artan trafik yükleri ve farklı çevre koşullarının etkileri ile kabul edilebilir bir $\left(\mathrm{p}_{\mathrm{t}}\right)$ değerine kadar azalma göstermektedir. AASHTO 1993 yöntemine göre $\left(\mathrm{p}_{\mathrm{o}}\right)$ değeri rijit yol üstyapıları için 4,5 olarak belirlenmiştir (Karayolları beton yol üstyapılar projelendirme rehberi, 2019). Çalışma kapsamında yapılan hesaplamalarda $\mathrm{p}_{0}=$ 4,5 ve Çizelge 3 'den $p_{t}=2,5$ olarak seçilmiştir.

Çizelge 3. Son Servis Yeteneği Değeri

\begin{tabular}{ll}
\hline Yolun Sinıf & $\mathbf{P}_{\mathbf{t}}$ \\
\hline Otoyol ve devlet yollarında & 2,5 \\
İl yollarında & 2,0
\end{tabular}

\subsubsection{Güvenilirlik}

Güvenilirlik, üstyapının trafik yüklerine karşı mininum bir dirençle karşı koyması durumunda meydana gelebilecek aksaklıkları gidermeye çalışması olarak ifade edilmektedir. Güvenilirlik seviyesi Çizelge 4 yardımı ile seçilmektedir (Karayolları Beton Yol Üstyapılar Projelendirme Rehberi, 2019).

Çizelge 4. Tavsiye Edilen Güvenilirlik Seviyeleri

\begin{tabular}{ll}
\hline Yolun sınıf & $\mathbf{R},(\boldsymbol{\%})$ \\
\hline Devlet yolları ve otoyollar & $80-99,9$ \\
İl yolları & $75-95$ \\
Toplayıcı yollar & $75-95$ \\
Tali ve mahalli yollar & $50-80$ \\
\hline
\end{tabular}

Ülkemiz için yapılacak tasarımlarda tavsiye edilen (R) değerleri, devlet yolları ile otoyollar için \%95; il yolları için ise
\%85 alınması öngörülmektedir. Güvenilirlik derecesine (R) bağlı olarak güvenilirliğin standart sapması $\left(Z_{R}\right)$ Çizelge 5 yardımı ile seçilir (Güngör ve Sağlık 2008).

Çizelge 5. Tavsiye Edilen Güvenilirlik Değerleri

\begin{tabular}{lcc}
\hline Yolun sınıfı & $\begin{array}{c}\text { Şartname güvenilirlik } \\
\text { değeri, R (\%) }\end{array}$ & $\begin{array}{c}\text { Standart } \\
\text { normal sapma, } \\
\mathbf{Z}_{\mathbf{R}}\end{array}$ \\
\hline Otoyollar & 95 & -1.645 \\
Devlet Yolu & 85 & -1.037 \\
İ Yolu & 70 & -0.524 \\
\hline
\end{tabular}

Çalışma kapsamında yapılan hesaplamalarda otoyollar ve devlet yolları için Çizelge 4'den (R) \%95 ve seçilen (R) değerine bağlı olarak Çizelge 5'den $Z_{R}$ değeri -1,645 olarak seçilmiştir.

Rijit üstyapılar için toplam standart sapma değerinin $\left(S_{o}\right)$ 0,35 olarak alınması önerilmektedir (Karayolları beton yol üstyapilar projelendirme rehberi, 2019).

\subsubsection{Taban zemini efektif reaksiyon modülü $(k)$}

Taban zemini için alınan efektif reaksiyon modülü $(\mathrm{k})$, beton (rijit) kaplamlarda efektif yatak katsayısı olarak da adlandırılır. Beton veya rijit plak kalınlık hesaplamaları öncesinde (k) değerinin belirlenmesi gereklidir. Bu değer Eşitlik 2 yardımı ile hesaplanmaktadır (Karayolları Beton Yol Üstyapılar Projelendirme Rehberi, 2019).

$$
k=P / Y
$$

Burada; P, Taban zeminine gelen yükü (psi veya $\mathrm{kg} / \mathrm{cm}^{2}$ ); Y, Çökme deformasyonunu (inç veya $\mathrm{cm}$ ) ve $\mathrm{k}$, Yatak katsayısıefektif reaksiyon modülünü ( $\mathrm{psi} / \mathrm{inç}$ veya $\mathrm{kg} / \mathrm{cm}^{2} / \mathrm{cm}$ ) ifade etmektedir.

$\mathrm{k}$ değeri, zeminin taşıma gücüne, yoğunluğuna, nem miktarına ve cinsine bağlı olarak değişiklik gösterebilmektedir. $\mathrm{k}$ katsayısının plaka yükleme testi ile tespit edilemediği şartlarda, taban zeminin (CBR) değeri belirlenir ve Şekil 2 eğrisi yardımı ile yaklaşık olarak tespit edilir (Yılmaz, Yıldıran ve Keskin 2017).

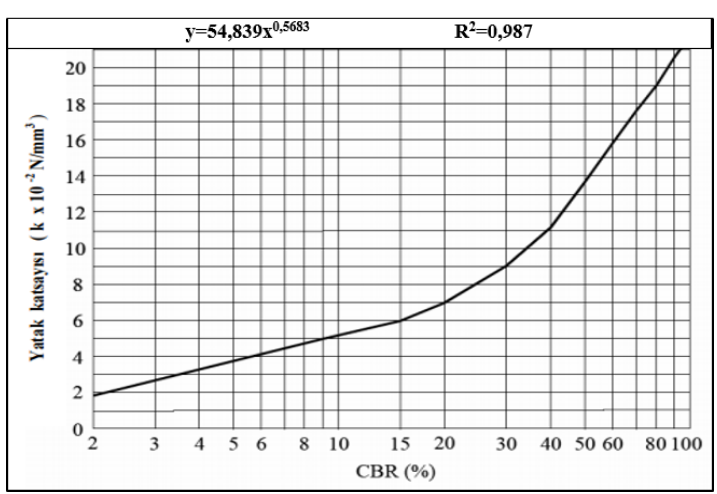

Şekil 2. CBR ile k Arasındaki Bağıntı Eğrisi (AASHTO 1993) 
Şekil 2'de verilen CBR ile taban reaksiyon modülü (k) arasında regresyon yapılmıştır. Yapılan regresyon sonucunda korelâsyon katsayısı ve $\mathrm{R}^{2}=0,987$ olarak bulunmuştur. Korelâsyon değeri 1'e çok yakın olduğundan pozitif güçlü korelâsyon vardır. Bu ilişki CBR değerinin artmasıyla, (k) değerinin da artmakta olduğunu göstermektedir. Regresyonda y bağımlısı yatak katsayısını (k), x bağımsızı ise CBR değerini ifade eder. Buna göre CBR ile (k) değeri arasındaki bağıntı Eşitlik 3'de görüldüğ̈̈ gibi ifade edilebilir.

$\mathrm{k}=54,839 \times \mathrm{CBR}^{0,5653}$

\subsubsection{Elastisite modülü $\left(E_{c}\right)$ ve portland çimentolu betonun kopma modülü (S'c)}

Betonun “j” günlük elastisite modülü $\left(\mathrm{E}_{\mathrm{cj}}\right)$ TS 500'e göre Eşitlik 4'de verilen bağıntı ile belirlenir.

$$
E_{c j}=3250 \sqrt{ } f_{c k j}+14.000 M P a
$$

Burada; $E_{c j}$, betonun “j” günlük elastisite modülünü (MPa), $f_{c k j}$ ise betonun " $\mathrm{j}$ ” günlük karakteristik silindir basınç dayanımını ( $\mathrm{MPa}, \mathrm{j}=28$ gün) ifade etmektedir. AASHTO tasarım rehberinde beton sınıflarına göre elastisite modülü $\left(\mathrm{E}_{\mathrm{c}}\right)$ değerleri Eşitlik 5 ile hesaplanmaktadır. $\mathrm{S}^{\prime}{ }_{\mathrm{c}}$, portland çimentosu ile hazırlanan betonun yaklaşık kopma modülünü (psi) $\left(6,8950 \times 10^{3}\right.$ $\mathrm{Pa}), \mathrm{E}_{\mathrm{c}}$ ise portland çimentolu betonun elastisite modülünü ( $\mathrm{psi}$ ) $\left(6,8950 \times 10^{3} \mathrm{~Pa}\right)$ ifade etmektedir.

$$
\mathrm{E}_{\mathrm{c}}=6750 \times \mathrm{S}_{\mathrm{c}}
$$

Eğilmede çekme dayanımı ve kopma modülü $\left(\mathrm{S}^{\prime}{ }_{\mathrm{c}}\right)$, 'Beton kirişin kırılma esnasında ulaştığı en yüksek eğilme-çekme gerilmesi’ olarak tanımlanır. Eğilmede çekme dayanımı, Şekil 3 'de görüldüğü gibi belirli boyuttaki beton bir kirişin 28 günlük kür sonunda orta nokta veya üç nokta yüklemesi altında kırılması ile hesaplanmaktadır (Karayolları Beton Yol Üstyapılar Projelendirme Rehberi, 2019).

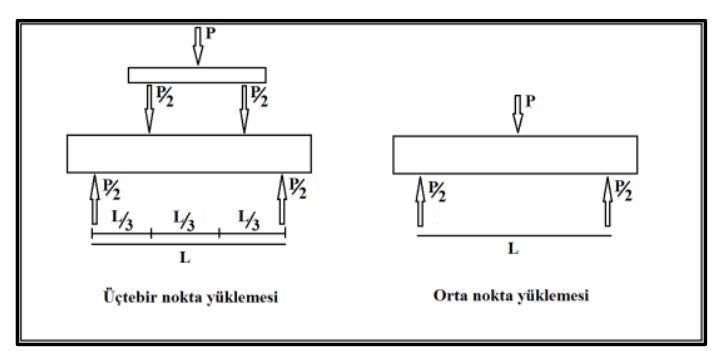

Şekil 3. Eğilme Direncinin Saptanması (Karayolları Beton Yol Üstyapılar Projelendirme Rehberi, 2019).

Kopma modülleri veya eğilme direçleri, bu yüklemeler altında üçte bir nokta yüklemesi için Eşitlik 6 ve orta nokta yükleme durumu için Eşitlik 7 bağıntıları ile hesaplanmaktadır.

$$
\begin{aligned}
& \mathrm{S}_{\mathrm{c}}=(\mathrm{P} \times \mathrm{L}) /\left(\mathrm{b} \times \mathrm{h}^{2}\right) \\
& \mathrm{S}_{\mathrm{c}}=(3 \times \mathrm{P} \times \mathrm{L}) /\left(2 \times \mathrm{b} \times \mathrm{h}^{2}\right)
\end{aligned}
$$

Burada; $\mathrm{S}_{\mathrm{c}}$, kopma modülü veya eğilme direncini; $b$, kiriş geniş̧liğini; $h$, kiriş yüksekliğini; $\mathrm{P}$, uygulanan yükü ve $\mathrm{L}$ ise uzunluk olarak ifade edilmektedir.

$E_{c}$ ve $S_{c}$ değerleri beton sınıflarına bağlı olarak Çizelge 6'da

\begin{tabular}{|c|c|c|c|c|c|c|c|c|}
\hline $\begin{array}{l}\text { Beton } \\
\text { sinifi }\end{array}$ & $\begin{array}{c}\text { Karakteristik } \\
\text { silindir basınç } \\
\text { dayanımı, } \\
\left(\mathrm{f}_{\mathrm{ck}}\right),(\mathrm{MPa})\end{array}$ & $\begin{array}{l}\text { Karakteristik } \\
\text { küp basınç } \\
\text { dayanımı, } \\
\left(\mathrm{f}_{\mathrm{ck}}\right)(\mathrm{MPa})\end{array}$ & $\begin{array}{l}\text { Eğilmede } \\
\text { çekme } \\
\text { dayanımı } \\
(\mathrm{MPa})\end{array}$ & $\begin{array}{c}\text { TS 500’e } \\
\text { göre yaklaşık } \\
\text { S' }{ }_{c}(p s i)\end{array}$ & $\begin{array}{l}\text { AASHTO’ya göre } \\
\text { yaklaşık } \\
\mathrm{S}_{\mathrm{c}} \\
(\mathrm{psi})\end{array}$ & $\begin{array}{l}\text { Ortalama } \\
\qquad \mathrm{S}_{\mathrm{c}} \\
(\mathrm{psi})\end{array}$ & $\begin{array}{c}\mathrm{E}_{\mathrm{c}} \\
(\mathrm{MPa})\end{array}$ & $\begin{array}{c}\mathrm{E}_{\mathrm{c}} \\
(\mathrm{psi})\end{array}$ \\
\hline C $30 / 37$ & 30 & 37 & 3,83 & 556 & 688 & 622 & 32.000 & 4.641 .206 \\
\hline C 35/45 & 35 & 45 & 4,20 & 610 & 709 & 660 & 33.000 & 4.786 .244 \\
\hline C $40 / 50$ & 40 & 50 & 4,43 & 643 & 731 & 687 & 34.000 & 4.931 .281 \\
\hline
\end{tabular}
verilmiştir (Karayolları Beton Yol Üstyapılar Projelendirme Rehberi, 2019).

Çizelge 6. Beton Sinıflarının $S^{\prime}{ }_{c}$ ve $E_{c}$ Değerleri

AASHTO 1993 tasarım rehberinde beton sinifi olarak C 35/45 seçilerek gerekli hesaplamaların yapılması önerilmektedir (Karayolları Beton Yol Üstyapılar Projelendirme Rehberi, 2019).
2.6.5. Drenaj Drenaj katsayısının $\left(C_{d}\right)$ beton kaplamalar için önerilen değerleri, Çizelge 7'de belirtilmiştir. Bu çalışmada, hesaplamalar için $\mathrm{C}_{\mathrm{d}}$ değeri 1 olarak alınmıştır. 
Çizelge 7. Beton Üstyapı için Önerilen Drenaj Katsayısı $\left(C_{d}\right)$ (Mahmoud, 2011)

\begin{tabular}{|c|c|c|c|c|c|c|}
\hline \multirow{2}{*}{$\begin{array}{l}\text { Drenaj } \\
\text { Kalitesi }\end{array}$} & \multirow{2}{*}{$\begin{array}{l}\text { Suyun } \\
\text { Süresi }\end{array}$} & \multirow[t]{2}{*}{ Uzaklaştırma } & \multicolumn{4}{|c|}{$\begin{array}{l}\text { Kaplamanın doygunluk seviyesine yakın su içeriğine maruz kaldığı sürenin } \\
\text { yüzdesi }\end{array}$} \\
\hline & & & $<\% 1$ & $\% 1-5$ & $\% 5-25$ & $>\% 25$ \\
\hline Çok İyi & 2 saat & & $1,25-1,20$ & $1,20-1,15$ & $1,15-1,10$ & 1,10 \\
\hline İyi & 1 gün & & $1,20-1,15$ & $1,15-1,10$ & $1,10-1,00$ & 1,00 \\
\hline Vasat & 1 hafta & & $1,15-1,10$ & $1,10-1,00$ & $1,00-0,90$ & 0,90 \\
\hline Kötü & 1 ay & & $1,10-1,00$ & $1,00-0,90$ & $0,90-0,80$ & 0,80 \\
\hline Çok Kötü & Dren yok & & $1,00-0,90$ & $0,90-0,80$ & $0,80-0,70$ & 0,70 \\
\hline
\end{tabular}

\subsubsection{Yük transfer katsayısı ( $\mathrm{J}$ )}

Derzlerde beton üstyapının yük nakletme yeteneğini ifade eden ve yük nakil katsayısı olarak adlandırılan (J) parametresi beton yol üstyapı projelendirilmesinde dikkate alınmaktadır
(Tanyıldızı, 2010). Projelendirme koşullarına göre yük transfer katsayıları Çizelge 8 'de verilmiştir. Bu çalışmada, tüm hesaplamalar için $\mathrm{J}=2,7$ olarak kabul edilmiştir.

Çizelge 8. Önerilen Yük Transfer Katsayıları (Tanyıldızı, 2010)

\begin{tabular}{lcccc}
\hline Banket & \multicolumn{2}{c}{ Asfalt } & \multicolumn{2}{c}{ Beton (Rijit) Kaplama } \\
\hline Yük Transferi & Var & Yok & Var & Yok \\
Donatısız derzli & 3,2 & $3,8-4,4$ & $2,5-3,1$ & $3,6-4,2$ \\
Donatılı derzli & 3,2 & $3,8-4,4$ & $2,5-3,1$ & $3,6-4,2$ \\
Sürekli donatılı derzsiz & $2,9-3,2$ & - & $2,3-2,9$ & - \\
\hline
\end{tabular}

\section{Bulgular ve Değerlendirme}

\subsection{Kıvam Limitleri Deney Sonuçları}

Deneysel çalışmalar kapsamında, katkısız saf kil ve belirlenen oranlarda $(\% 0, \% 5, \% 10, \% 15$ ve $\% 20)$ hazırlanan karışımlar üzerinde TS 1900-1'e uygun olarak likit limit ve plastik limit deneyleri yapılmıştır. Deneylere tabi tutulan numunelerin 7 günlük kür süresinin sonundaki sonuçları Şekil 4’te verilmiştir.

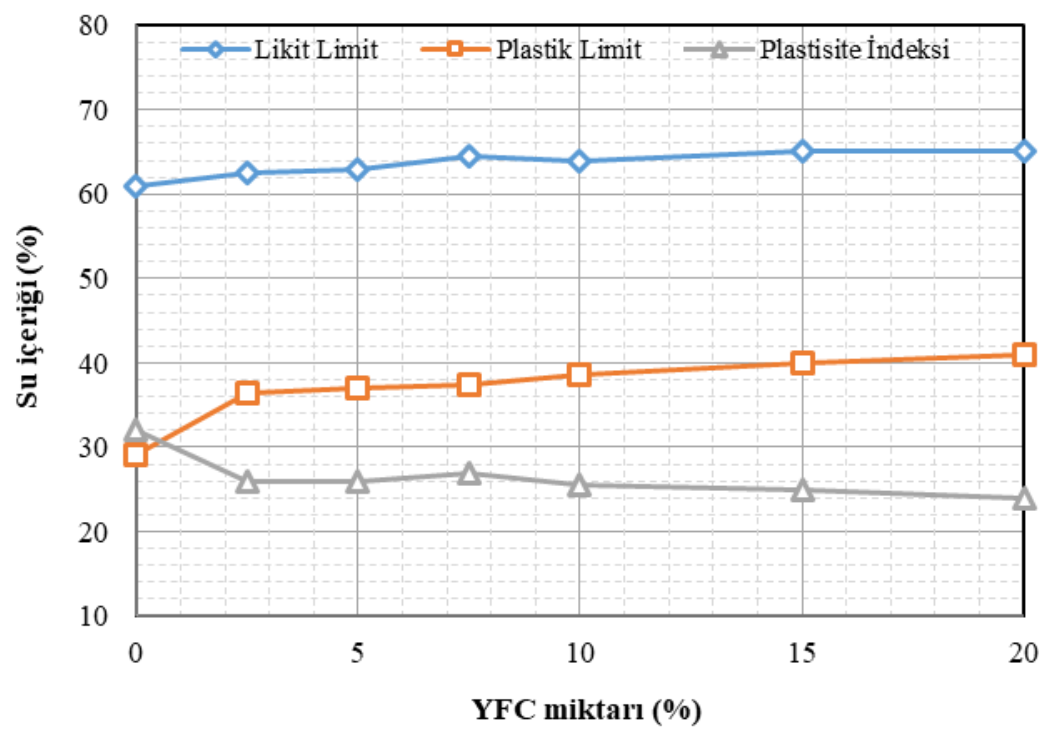

Şekil 4. Karışımların Kıvam Limitlerindeki Değişim

Şekil 4 dikkate alındığında, YFC artışına bağlı olarak karışımların likit limit değerlerinde daha az ancak plastik limit değerlerinde ise daha fazla artış gözlemlenmektedir. $\mathrm{Bu}$ değişimlere bağlı olarak plastisite indeksi (PI) değerlerinde bir azalma görülmektedir. Plastisite indeksindeki azalma, YFC ilavesiyle zeminlerin su hassasiyetinin azaldığını ifade etmektedir. Ayrıca, bu azalma ile bağlantılı olarak zeminin işlenebilirlik özelliğinin artış göstereceği ifade edilebilir.

\subsection{Standart Proctor Deney Sonuçları}

Yapılan kompaksiyon (standart proktor) deneyinde, stabilize numuneler optimum su oranı tayini için deneye tabi tutulurken, YFC'nin karışımdaki puzolanik reaktivitesini arttırmak ve zemin ile arasında iyi bir aderans temin etmek amaciyla su yerine Sodyum Hidroksit $(\mathrm{NaOH})$ solisyonu eklenmiştir. Kristal haldeki sodyum hidroksit ve suyun karışımından elde edilen solisyonun karışım oranı 320 gr/lt şeklindedir. Yani 1 litre suya 320 gr 
sodyum hidroksit eklenmiştir. Ardından TS 1900-1 standardına göre saf kil zemin ve her bir karışım için ( $\% 0, \% 5, \% 10, \% 15$ ve $\% 20$ ) numuneler hazırlanmış ve bu numeneler standart proktor deneylerine tabi tutulmuştur. Deney sonucunda numunelerin su oranına bağlı kuru yoğunluk grafikleri Şekil 5 'te gösterilmiştir.

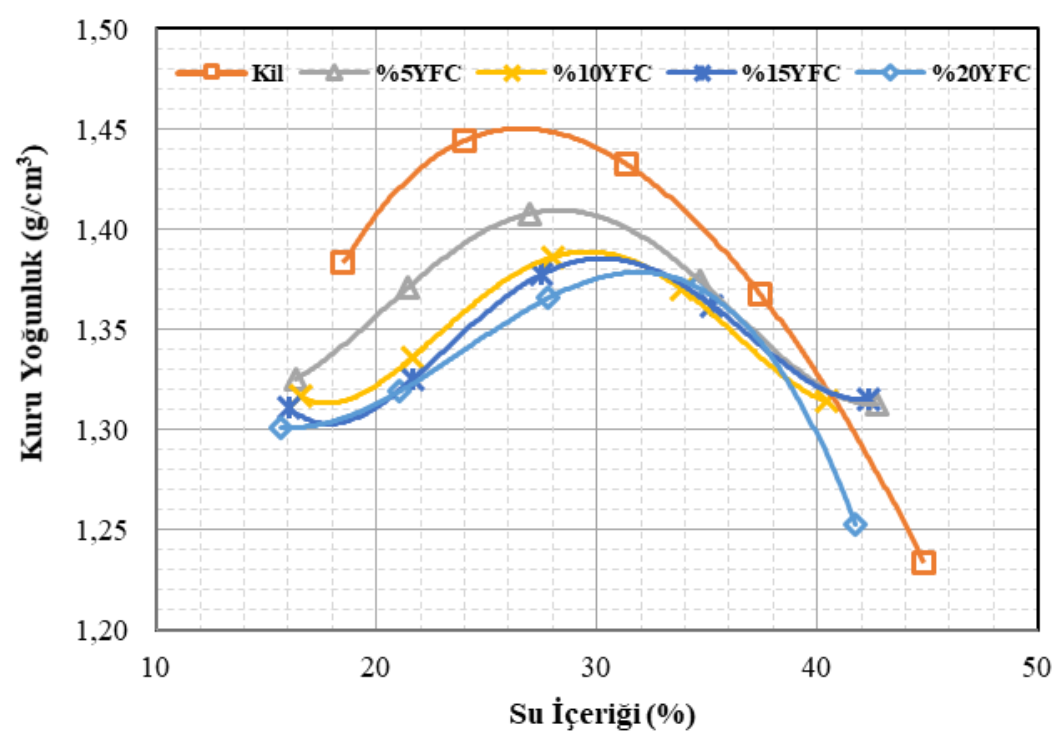

Şekil 5. Numunelere Ait Kuru Yoğunluk - Su İçeriği Grafikleri

Şekil 5 incelendiğinde, YFC miktarındaki artışa bağlı olarak numunelerin optimum su içeriğinde artış, maksimum kuru yoğunluklarında ise azalma meydana geldiği tespit edilmiştir. Numunelerin maksimum kuru yoğunluklardaki optimum su muhtevalar1 $\left(\mathrm{W}_{\text {opt }}\right)$ sirasiyla \%27, \%28,5, \%29,5, \%30,5 ve \%31 olarak elde edilmiştir. Su muhtevasındaki artışın ve kuru yoğunlukta meydana gelen azalmanın, YFC'nin yüksek su emme potansiyeli ve ince taneli yapıya sahip olmasından kaynaklandığ (Arulrajah, Mohammadinia, Horpibulsuk ve Samingthong, 2016) düşünülmektedir.

\subsection{Tek Eksenli Serbest Basınç Deney Sonuçları}

Deney kapsamında her numune için belirlenen $\mathrm{W}_{\text {opt }}$ değerleri esas alınarak tek eksenli serbest basınç deneyleri için karışım numuneleri hazırlanmıştır. Her bir karışım için üçer adet numune hazırlanıp, 7 ve 28 günlük kür süresine tabi tutulmuş ve bu süre sonunda serbest basınç deneyi yapılmıştır. Karışım numunelerinin 7 ve 28 günlük kür süresi sonucunda bulunan Gerilme-Şekil değiştirme grafikleri sırasıyla Şekil 6 ve Şekil 7’de verilmiştir.

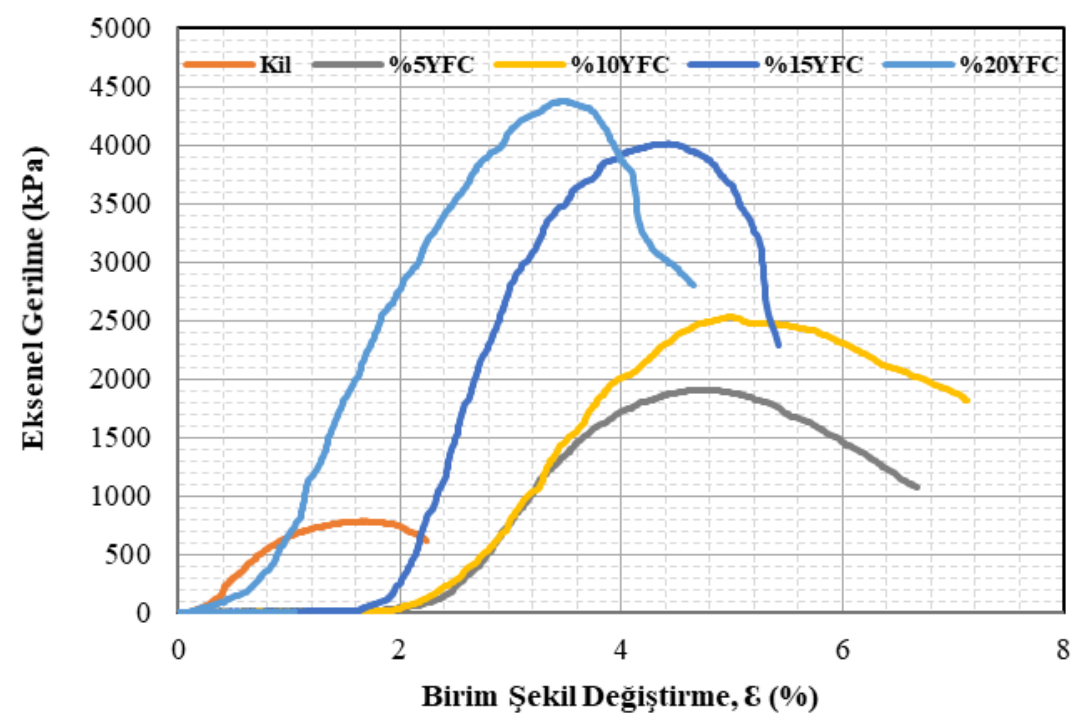

Şekil 6. Numunelerin Serbest Basınç Deney Grafikleri (7 Günlük Kür) 


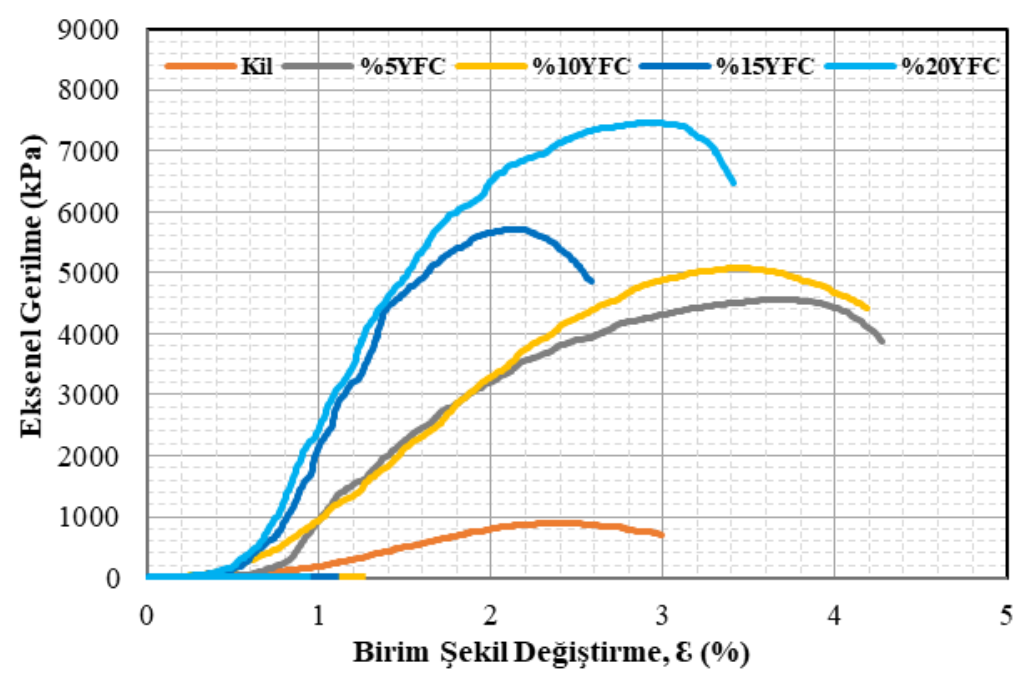

Şekil 7. Numunelerin Serbest Basınç Deney Grafikleri (28 Günlük Kür)

Şekil 6 ve Şekil 7'de görüldüğü gibi, YFC artışı ile zeminlerin dayanımlarının arttığı ve karışımlar içerisinde en yüksek serbest basınç dayanımlarının \%20YFC katkılı kil numunelere ait olduğu görülmektedir. 28 günlük kür süresi sonunda \%20YFC katkısı ile stabilize edilen kilin serbest basınç dayanımında önemli miktarda artış olduğu gözlemlenmiştir. Bu durumun, YFC'nin puzolanik bir malzeme olması ve puzolanik malzemelerin daha geç dayanım kazanmasından kaynaklandığı değerlendirilmektedir. Ancak, YFC kullanılarak yapılan önceki çalışmalar (Sivrikaya, Yavaşcan ve Çeçen 2014; Bilgen, Kavak ve Çapar 2012; Kelly, 2008) dikkate alındığında maksimum dayanımı veren oranların birbirinden farklılık gösterdiği görülmektedir. Yapılan literatür incelemeleri neticesinde bu farklılığın çalışmada kullanılan killerin ve YFC'nin yapısal farklılıklarından ve puzolanik reaksiyonu artırmak için kullanılan çözeltilerin cins ve miktarından kaynaklandığı görülmektedir.

\subsection{CBR Deney Sonuçları}

Serbest Basınç deneyleri sonucunda, en efektif katkı oranı $\% 20$ olarak tespit edildikten sonra, hazırlanan saf ve stabilize karışım numuneleri CBR deneyine tabi tutulmuştur. Bu amaçla, saf kil ve \%20YFC içeren karışım numuneleri ikişer adet hazırlanarak 7 ve 28 günlük kür süresine tabi tutulmuştur.

Numunelerin, 7 günlük kür süresi sonucunda elde edilmiş olan yük-deplasman grafiği Şekil 8'te, tespit edilen CBR değerleri ise Çizelge 9'da gösterilmiştir.

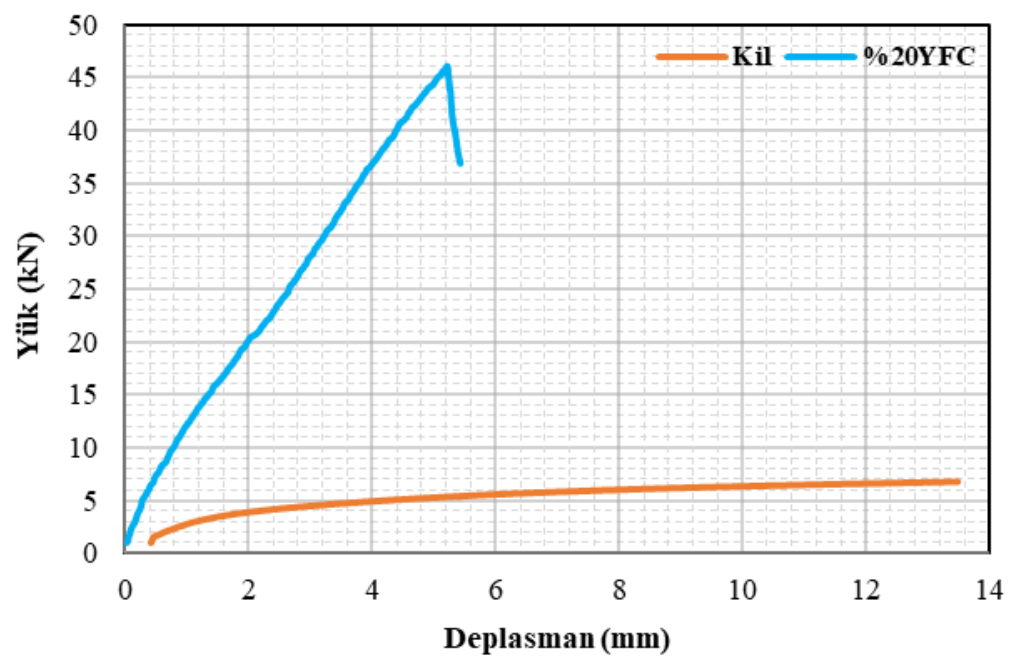

Şekil 8. Numunelerin Yük-Deplasman Davranışı (7 Günlük Kür)

Çizelge 9. Numunelerin 7 Günlük Kür Sonundaki CBR Değerleri

\begin{tabular}{lccc}
\hline Numune & Kür Süresi & CBR (2,5 mm), (\%) & CBR (5 mm), (\%) \\
\hline Saf Kil & \multirow{2}{*}{ günlük } & 31,2 & 25,6 \\
Saf Kil+\%20 YFC & & 179,7 & 222,9 \\
\hline
\end{tabular}

CBR deney sonuçlarına göre, 2,5 ve $5 \mathrm{~mm}$ 'lik deplasmanlara ait 7 günlük kürün sonucunda $\mathrm{CBR}$ değerleri saf kil zemin için sırasıyla \%31,2 ve $\% 25,6 ; \% 20$ YFC katkılı zemin için \%179,7 ve \%222,9 olarak elde edilmiştir. Bu kür sonucunda \%20YFC katkısı ile saf kil zeminin CBR değeri takribi olarak 7,14 kat artış göstermiştir. Saf ve \%20YFC katkılı zeminlerin 28 günlük kür sonucunda elde edilmiş olan yük-deplasman grafiği ise Şekil 9'da, tespit edilen CBR değerleri de Çizelge 10'da gösterilmiştir. 


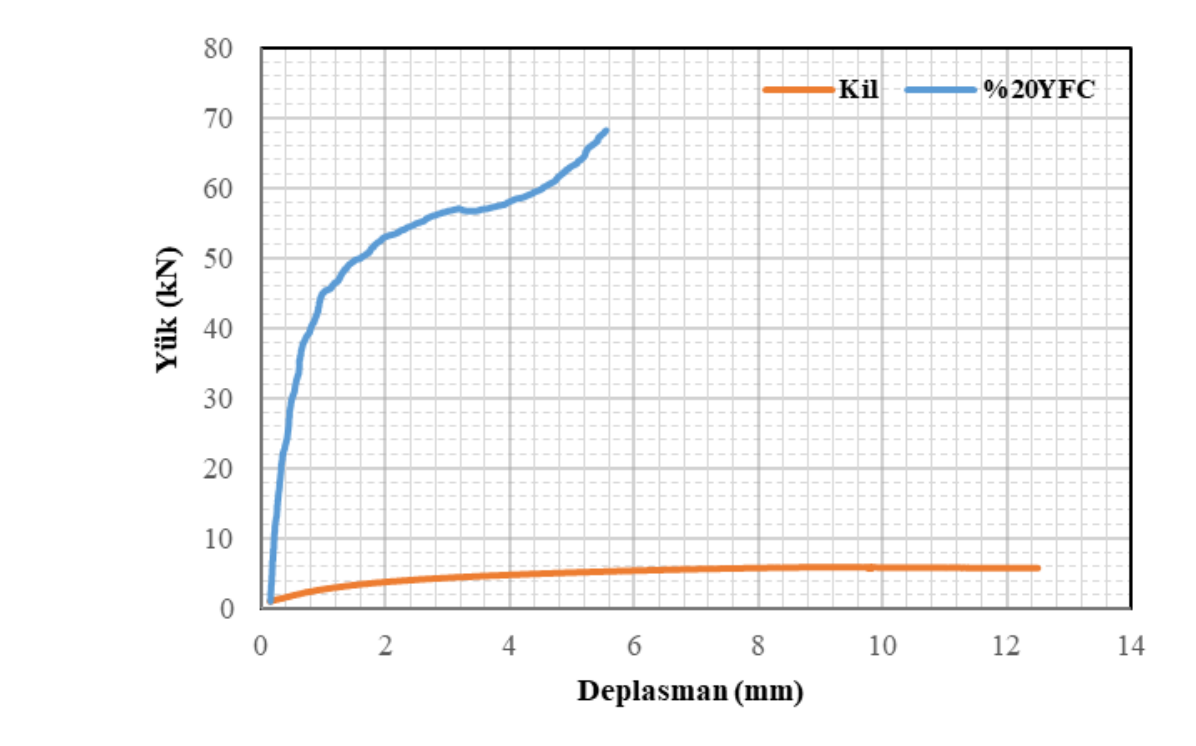

Şekil 9. Numunelerin Yük-Deplasman Davranışı (28 Günlük Kür)

Çizelge 10. Numunelerin 28 Günlük Kür Sonundaki CBR Değerleri

\begin{tabular}{lccc}
\hline Numune & Kür Süresi & CBR (2,5 mm), (\%) & CBR (5 mm), (\%) \\
\hline Saf Kil & \multirow{2}{*}{ 28 günlük } & 32 & 26,4 \\
Saf Kil+\%20 YFC & & 416,04 & 315,63 \\
\hline
\end{tabular}

Deney sonuçlarına göre, 28 günlük kür sonucunda 2,5 ve 5 mm'lik deplasmanlara karşılık gelen CBR değerleri saf kil zemin için sırasıyla $\% 32$ ve $\% 26,4 ; \% 20$ YFC katkılı zemin için sırasıyla $\%$ 416,04 ve \% 315,63 olarak elde edilmiştir. Bu kür sonucunda \% 20YFC katkısı saf killi zeminin CBR değerini takribi olarak 13 kat artırmış̧ır. $\mathrm{Bu}$ artışlar, killi zeminlerin taşıma gücü üzerinde YFC'nin oldukça iyileştirici bir etkiye sahip olduğunu ve bu sonucun önceki çalışmalar (Kuloğlu, Özden ve Kayalar, 2006) ile uyumlu olduğunu göstermektedir.

\subsection{AASHTO Metodu ile Rijit Üstyapı Tasarım Sonuçları}

Rijit üstyapı tasarımı için AASHTO (1993) tasarım rehberine göre, katkısız saf ve \%20YFC katkılı yol taban zemini esas alınarak hesaplamalar yapılmıştır. Tasarımda, derzli donatısız rijit yol kaplama kalınlığı etüt edilmiştir. $\mathrm{Bu}$ etüt yapılırken hesaplamalarında kullanılan parametreler Çizelge 11 'de verilmiştir. Hesaplamalarda, farklı trafik değerleri için Eşitlik 1 yardımıyla beton kaplama kalınlıkları hesaplanmıştır.

Çizelge 11. Rijit Kaplama Hesaplamalarında Kullanılan Parametreler

\begin{tabular}{ll}
\hline Parametreler & Seçilen Değer \\
\hline 8,2 ton eşdeğer tek-dingil yükü tekerrür sayısı, $\mathrm{W}_{8.2}$ & $75 \times 10^{6}, 100 \times 10^{6}, 125 \times 10^{6} \mathrm{ve} 150 \times 10^{6}$ \\
Yük transfer katsayısı, $\mathrm{J}$ & 2,7 \\
Drenaj katsayısı, $\mathrm{C}_{\mathrm{d}}$ & 1 \\
Trafik tahmini ve performans tahmininin standart hatası, $\mathrm{S}_{0}$ & 0,35 \\
$\% 95 \mathrm{R}_{\mathrm{E}}$ için, Standart normal sapma, $\mathrm{Z}_{\mathrm{R}}$ & $-1,645$ \\
Betonun elastisite modülü, $\mathrm{E}_{\mathrm{c}}(\mathrm{psi})\left(6,8950 \times 10^{3} \mathrm{~Pa}\right)$ & 4.786 .244 \\
Servis yeteneği kaybı, $\Delta \mathrm{PSI}(\mathrm{psi}), \Delta \mathrm{PSI}=\mathrm{P}_{0}-\mathrm{P}_{\mathrm{t}}=2$ & 2 \\
Betonun kopma modülü $\left(\mathrm{S}^{\prime}{ }_{\mathrm{c}}\right)(\mathrm{psi})\left(6,8950 \times 10^{3} \mathrm{~Pa}\right)$ & 660 \\
Taban reaksiyon modülü, $\mathrm{k}(\mathrm{pci})\left(27679,9 \mathrm{~kg} / \mathrm{m}^{3}\right)$ & $\mathrm{k}_{\mathrm{kil}}=393,07, \mathrm{k}_{\% 20 \mathrm{YFC} \text { katkll kil }}=1658,30$ \\
\hline
\end{tabular}

Katkısız kil zeminin ( $\mathrm{k}=393,07$ pci) farklı trafik yükleri için $\left(75 \times 10^{6}, 100 \times 10^{6}, 125 \times 10^{6}\right.$ ve $\left.150 \times 10^{6}\right)$ kaplama kalınlıkları Eşitlik 1 yardımıyla hesaplanarak sırasıyla 12,56, 13,13, 13,60 ve 13,99 inç olarak hesaplanmıştır. Benzer şekilde \%20YFC katkılı kil zeminin de aynı trafik değerlerindeki kaplama kalınlıkları belirlenerek bütün sonuçlar Çizelge 12'de verilmiştir. Kaplama kalınlıklarının trafikle değişim grafiği ise Şekil $10^{\text {'da }}$ gösterilmiştir. 
Çizelge 12. Saf ve \%20 YFC Katkılı Kil Zeminlerin Beton Kaplama Kalınlıkları

\begin{tabular}{ccccc}
\hline \multirow{2}{*}{ Proje Trafiği $\left(\mathbf{W}_{\mathbf{8 . 2}}\right) \mathbf{x} \mathbf{1 0}^{\mathbf{6}}$} & \multicolumn{2}{c}{ Saf kil zemin } & \multicolumn{2}{c}{ \%20YFC katkll kil zemin } \\
& d (inc) & d (cm) & d (inc) & d (cm) \\
\hline 75 & 12,56 & 31,90 & 11,35 & 28,83 \\
100 & 13,13 & 33,35 & 11,96 & 30,38 \\
125 & 13,60 & 34,54 & 12,42 & 31,55 \\
150 & 13,99 & 35,53 & 12,82 & 32,56 \\
\hline
\end{tabular}

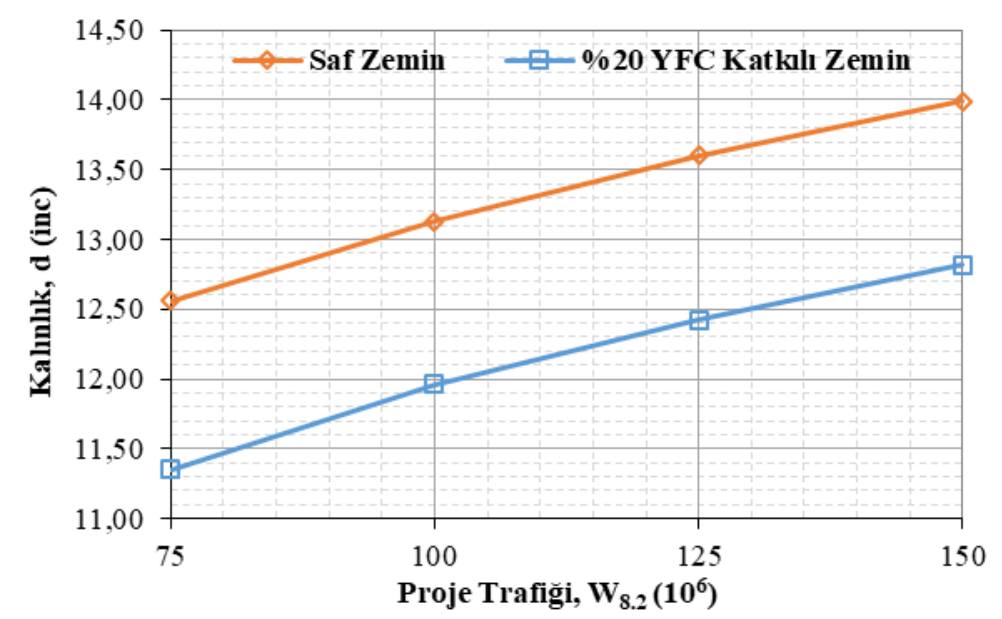

Şekil 10. Saf ve \%20YFC Katkılı Kil Zeminlerin $\mathrm{W}_{8,2}-\mathrm{d}$ Değişim Grafiğgi

Şekil 10 incelendiğinde, rijit üstyapı tasarımında yol taban zemini olarak saf kil yerine $\% 20$ YFC katkılı kil zemin kullanılması durumunda üstyapı tabaka kalınlığında önemli bir azalma meydana geldiği görülmektedir. Bu azalma, artan trafik değerlerine göre saf zemine kıyasla sirasiyla $3,07 \mathrm{~cm}, 2,97 \mathrm{~cm}$, $2,99 \mathrm{~cm}$ ve $2,97 \mathrm{~cm}$ olarak gerçekleşmiştir. Bu durumda benzer ağır trafik etkilerine maruz bir yolda, yol zemininin YFC ile stabilize edilmesiyle rijit üstyapı kalınlığının ciddi oranda azalacağını ve bunun yol maliyetini önemli ölçüde düşüreceğini ifade etmek mümkündür.

\subsection{Rijit Üsyapının Ekonomik Analizi}

YFC ile iyileştirilmiş zeminin karayolu rijit üstyapı maliyeti üzerindeki etkisi, Çevre ve Şehircilik Bakanlığı (ÇŞB) tarafından yayınlanmış olan 2020 y1lı birim fiyat cetvellerinden (http://www.birimfiyat.net 2020) öncelikle C 35/45 basınç sınıfindaki beton kaplama ve temel için birim alan maliyetleri hesaplanmıştır. Maliyet hesabında; her bir tabakanın maliyeti, birim fiyatların tabakanın kendi kalınlığına bölünerek " $\mathrm{m}^{2} / \mathrm{cm}$ " cinsinden hesaplanması ile elde edilmiş ve bunların toplamıla üstyap1 birim maliyeti 4,05 TL olarak belirlenmiştir. Hesaplamalarda, beton plak altına AASHTO tarafından önerilen $20 \mathrm{~cm}$ kalınlığındaki plentmiks temel (PMT) esas alınmıştır.

ÇŞB'nin 2020 yılı birim fiyatları ve tabakaların birim maliyetleri Çizelge 13'te verilmiştir.

Çizelge 13. Rijit Üstyapı İçin Birim Maliyetler

\begin{tabular}{ccccc}
\hline Poz No & Tanım & Birim & $\begin{array}{c}\text { Birim Fiyat } \\
(\mathrm{TL})\end{array}$ & $\begin{array}{c}\text { Maliyet } \\
\left(\mathrm{m}^{2} / \mathrm{cm}\right),(\mathrm{TL})\end{array}$ \\
\hline
\end{tabular}

Beton santralinde üretilen veya satın alınan ve beton pompasıyla basılan, C 35/45 basınç dayanım sınıfında,

15.150 .1007 gri renkte, normal hazır beton dökülmesi (beton nakli $\mathrm{m}^{3}$ 278,63 2,78 dahil)

KGM/6100/3

Plentmix temel yapılması (kırılmış ve elenmiş ocak taşı ile) Not: Kaplama yoğunluğu $2,4 \mathrm{gr} / \mathrm{cm}^{3}$

ton $\quad 53,21$ 1,27

Çizelge 13'teki veriler esas alınarak, saf ve \%20YFC katkılı zeminlerin farklı trafik değerleri için rijit üstyapı birim maliyetleri ve maliyetlerdeki değişim hesaplanmış ve sonuçları Çizelge 14'te verilmiştir. Zeminlerin kalınlıklarındaki ve maliyetlerindeki azalma ise Şekil 11 ve 12'de gösterilmiştir. 
Çizelge 14. Saf ve \%20YFC Katkılı Zeminler için Rijit Üstyapı Birim Maliyetleri

\begin{tabular}{cccccc}
\hline $\begin{array}{c}\text { Trafik } \\
\left(\mathbf{W}_{\mathbf{8}, \mathbf{2}}\right) \mathbf{x} \mathbf{1 0}^{\mathbf{6}}\end{array}$ & $\begin{array}{c}\text { Saf zemin } \\
\text { (d) (inc) }\end{array}$ & $\begin{array}{c}\text { \%20YFC katkıl } \\
\text { zemin } \\
\text { (d) (inc) }\end{array}$ & $\begin{array}{c}\text { Saf zemin için } \\
\mathbf{1} \mathbf{~ m}^{\mathbf{2}} \text { maliyeti (TL) }\end{array}$ & $\begin{array}{c}\text { \%20YFC katkılı } \\
\text { zemin için } \mathbf{1} \mathbf{~ m}^{\mathbf{2}} \\
\text { maliyeti (TL) }\end{array}$ & $\begin{array}{c}\text { d'deki ve } \\
\text { maliyetteki } \\
\text { azalma (\%) }\end{array}$ \\
\hline 75 & 12,56 & 11,35 & 50,87 & 45,97 & 9,63 \\
100 & 13,13 & 11,96 & 53,18 & 48,44 & 8,91 \\
125 & 13,60 & 12,42 & 55,08 & 50,30 & 8,68 \\
150 & 13,99 & 12,82 & 56,66 & 51,92 & 8,36 \\
\hline
\end{tabular}

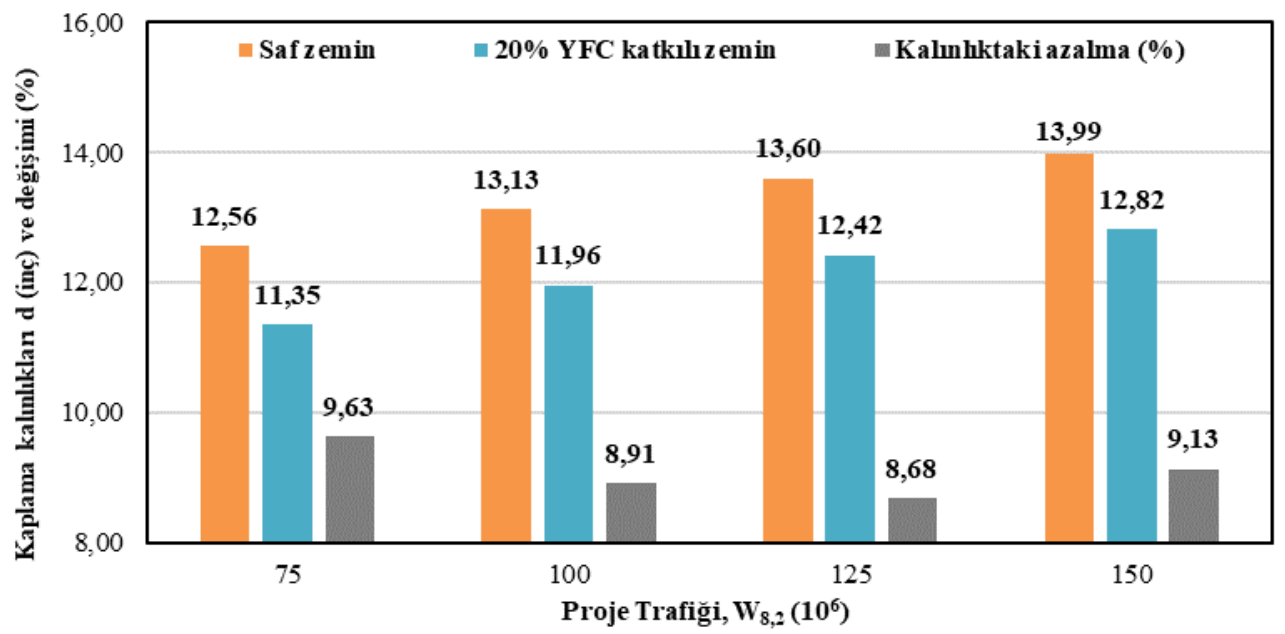

Şekil 11. Farklı Trafik Değerlerine Göre Rijit Kaplama Kalınlıklarındaki Değişim

Şekil 11'de görüldüğü gibi farklı trafik değerlerine bağlı olarak, rijit kaplama kalınlıklarında saf zemine kıyasla sırasıyla \% 9,63, \% 8,91, \% 8,68 ve \% 8,36 azalma meydana gelmiştir. Bu durumun, YFC kullanımının kaplama kalınlığının azalmasında önemli bir etkiye sahip olduğunu ve yolun maliyetinin azalmasına etki ederek kaplamanın ilk yapım maliyetini düşürdüğü tespit edilmiştir.

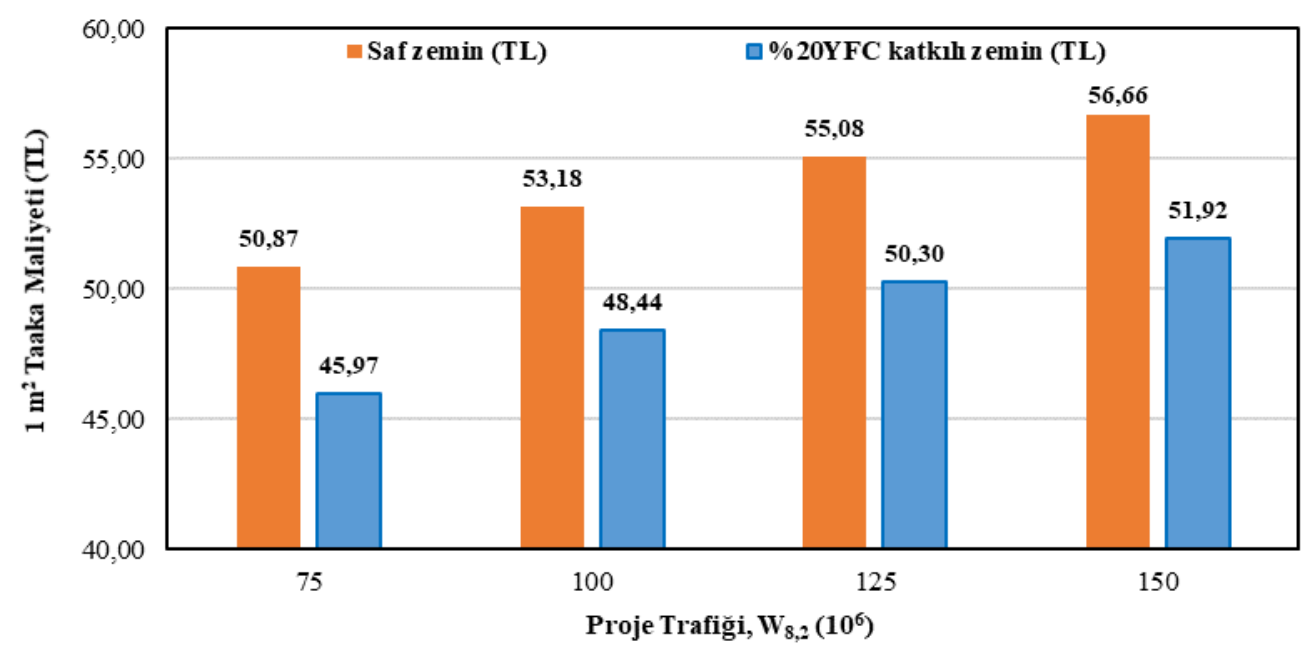

Şekil 12. Farklı Trafik Değerlerine Göre Rijit Kaplama Kalınlıklarındaki Maliyet Değişimi

Şekil 12'de verilen maliyette azalış oranları dikkate alınarak, proje trafiği $\mathrm{W}_{8,2}=75 \times 10^{6}$ olan rijit bir üstyapıda; saf kil zemin yerine \%20 YFC katkılı kil zemine göre tasarım yapılması durumunda, çift şeritli bölünmüş (platform genişliği $20 \mathrm{~m}$ ) 1000 $\mathrm{m}$ uzunluğundaki yolda $20 \times 1000 \times 0,0963=1.926 \mathrm{TL}$ maliyet azalış1 olduğu tespit edilmiştir. Benzer şekilde proje trafiği $100 \times 10^{6}, 125 \times 10^{6}$ ve $150 \times 10^{6}$ olan rijit üstyapilarda sirasiyla $1.782 \mathrm{TL}, 1.736 \mathrm{TL}$ ve $1.672 \mathrm{TL}$ maliyet azalışı meydana gelmektedir. Bu durumun YFC'nin kaplamanın kalınlığı ve maliyeti üzerinde önemli bir etkiye sahip olduğunu göstermektedir.

\section{Sonuçlar ve Öneriler}

YFC ilave edilerek dayanımı arttırılan killi bir yol taban zemininin, karayolu rijit üstyapı tabaka kalınlıklarına ve 
maliyetlerine etkilerinin araştırıldığı bu çalışmada aşağıdaki sonuçlar elde edilmiştir;

* Kil zeminin içeriğindeki YFC miktarının artmasına bağ $l_{1}$ olarak, karışımların optimum su muhtevalarında artış, maksimum kuru yoğunluk değerlerinde ise azalma görülmüştür. Bu durumun YFC'nin yüksek su emme potansiyeli ve ince taneli yapıya sahip olmasından kaynaklandığı düşünülmektedir.

* Serbest basınç deneyi sonuçlarına göre, YFC ilavesi ile saf zeminin serbest basınç dayanım artmış ve en yüksek dayanım \%20 YFC içeren karışımlardan elde edilmiştir. Bu sonuç, kil zeminin kayma direnci ve kohezyon yeteneği üzerinde YFC'nin iyileştirici bir etkiye sahip olduğunu göstermektedir.

* CBR deney sonuçlarına göre, \%20 YFC içeren karışımların $2,5 \mathrm{~mm}$ ve $5 \mathrm{~mm}$ 'lik deplasmanlara karşılık gelen CBR değerleri, saf zeminlere kıyasla sırasıyla 7,14 ve 13 kat fazla elde edilmiştir. $\mathrm{Bu}$ önemli artışlar, kil zeminin kalıcı deformasyon direnci üzerinde YFC'nin çok olumlu bir etkiye sahip olduğunu göstermektedir.

* Hesaplamalar neticesinde \%20 YFC ilaveli yol taban zemini üzerine oturan rijit üstyapının, kil zemin üzerine inşa edilen rijit üstyapıya nazaran $\% 9,63, \% 8,91, \% 8,68$ ve $\% 8,36$ oranlarında daha düşük kalınlıkta inşa edilebileceği görülmüştür.

* Aynı proje trafik değerlerinde, \%20 YFC katkılı kil zemine göre tasarım yapılması durumunda, çift şeritli bölünmüş (platform genişliği $20 \mathrm{~m}) 1000 \mathrm{~m}$ uzunluğundaki yolda saf kil zemine kıyasla sirasiyla $1.926 \mathrm{TL}, 1.782 \mathrm{TL}, 1.736 \mathrm{TL}$ ve $1.672 \mathrm{TL}$ maliyet azalışı sağlanmıştır.

Çalışma sonucunda, değişik trafik yükü altında killi bir zemine YFC ilave edilmesiyle zeminin dayanımının önemli ölçüde arttığı, rijit yol üstyapı tabaka kalınlıklarının ve yapım maliyetlerinin önemli ölçüde azaldığı tespit edilmiştir. $\mathrm{Bu}$ sebeple, zeminlerinin YFC ile iyileştirilmesi durumunda yol üstyapı maliyeti ve YFC'nin çevreye verdiği zararı önlemek bakımından çok faydalı olacağı düşünülmektedir.

\section{Teşekkür}

Bu çalışma, İnönü Üniversitesi Bilimsel Araştırma Projeleri (BAP) Koordinasyon Birimi, FBG-2018-957 numaralı projesi ile desteklenmiştir.

\section{Kaynaklar}

ACI, 2005. Ground granulated blast-furnace slag as a cementitious constituent in concrete reported by acı committe 233, American Concrete Institude, Detroit, Michigan.

American Association of State Highway and Transportation Officials, 1993. AASHTO Guide for Design of Pavement Structures. Washington, D.C.

Aruntaş H.Y, 2006. Uçucu küllerin inşaat sektöründe kullanım potansiyeli, Gazi Üniversitesi Mühendislik ve Mimarlık Fakültesi Dergisi, 21(1), 193-203.

Arulrajah A., Mohammadinia A., Horpibulsuk S., Samingthong $\mathrm{W}, 2016$. Influence of class f fly ash and curing temperature on strength development of fly ash-recycled concrete aggregate blends, Construction and Building Materials, 127, 743-750.

Bayrak O.Ü, 2007. Rijit üstyapı tasarımına yeni bir yaklaşım, Doktora tezi, Atatürk Üniversitesi Fen Bilimleri Enstitüsü, Erzurum.

Bilge T, 2011. Yüksek firın cürufu katkısının kil zeminlerin stabilizasyonuna etkisinin araştırılması, Balıkesir
Üniversitesi, Fen Bilimleri Enstitüsü, Yüksek Lisans Tezi, Balıkesir.

Bilgen G., Kavak A., Çapar Ö.F, 2012. Düşük plastisiteli bir kilde katkı olarak çelikhane cürufunun kullanılması ve kireç ile etkileşimi, Karaelmas Fen ve Mühendislik Dergisi, 2(2):3038.

Bilgen G, 2007. Yüksek firın cürufu ile zemin stabilizasyonu. Kocaeli Üniversitesi, Fen Bilimleri Enstitüsü, Yüksek Lisans Tezi, Kocaeli.

Bilgen G., Kavak A., Yıldırım S.T, Çapar Ö.F, 2010. Yüksek fırın cürufunun inşaat sektöründeki yeri ve önemi. 2'nci Ulusal Katı Atık Yönetimi Kongresi Bildirileri, Cilt 1: 506513, Mersin.

Cokca E., Yazıcı V., Özaydın V, 2009. Stabilization of expansive clays using granulated blast furnace slag (GBFS) and GBFS-cement. Geotechnical and Geological Engineering. 27: 489-499.

Çakılcıŏlu İ, 2007. Yüksek plastisiteli killerin stabilizasyonu. Yüksek Lisans Tezi, Sakarya Üniversitesi Fen Bilimleri Enstitüsü, Sakarya.

J. Emery, C. Kim, and R. Cotsworth, "Base Stabilization Using Pelletized Blast Furnace Slag,"Journal of Testing and Evaluation 4, no. 1 (1976): 94-100.

Gökalp İ., Uz V.E., Saltan M., and Tutumluer E, 2018. Technical and environmental evaluation of metalurgical slags as aggregate for sustainable pavement layer applications. Transportation Geotechnics, 14, 61-69.

Gurer C., Akbulut H., Kurklu G, 2004. İnşaat endüstrisinde geri dönüşüm ve bir hammadde kaynağı olarak farklı yapı malzemelerinin yeniden değerlendirilmesi, 5 'inci Endüstriyel Hammaddeler Sempozyumu, İzmir, Türkiye.

Güngör A.G., ve Sağlık A, 2008. Karayolları esnek üst yapılar projelendirme rehberi, Karayolları Genel Müdürlüğü, Teknik Araştırma Dairesi Başkanlığı, Ankara.

Hausman M.R, 1990. Engineering principles of ground modification. International Edition, 321-335.

Huang Y., Wang Q., and Shi M, 2017. Characteristics and reactivity of ferronickel slag. Construction and Building Materials, 156, 773-789.

http://www.birimfiyat.net, 2020. Erişim tarihi Ocak 23, 2021.

Karayolları Beton Yol Üstyapılar Projelendirme Rehberi, Türkiye, 2019.

Kavak A., Bilgen G, 2005. Yüksek firın cürufu ve kirecin katkı olarak kil üzerindeki etkileri ve yol yapımında kullanımının araştırılması, Geoteknik Sempozyumu, Adana.

Kelly B.C, 2008. Geo-engineering properties of granulated blast furnace slag. International Conference on Geotechnical Engineering, Hammamet, Tunisia.

Kılıç G, 2008. Çimento ile zemin stabilizasyonu, Yüksek Lisans Tezi, Yıldız Teknik Üniversitesi Fen Bilimleri Enstitüsü, İstanbul.

Kodikara J., Yeo R, 2005. Performance evaluation of road pavements stabilized in situ, Editor: Zhang L. Elsevier GeoEngineering Book Series, 409-443, Elsevier Science.

Kuloğlu M., Özden G., Kayalar A, 2006. Çelik cüruflarının dolgu malzemesi olarak kullanılabilirliği üzerine bir araştırma. Zemin Mekaniği ve Temel Mühendisliği 11'inci Ulusal Kongresi 7-8 Eylül Karadeniz Teknik Üniversitesi, Trabzon, 192-201.

Mahmoud M.K, 2011. Fırın cürufu katkısının zeminlerin mühendislik özellikleri üzerine etkisi, Dokuz Eylül Üniversitesi Fen Bilimleri Enstitüsü, Yüksek Lisans Tezi, İzmir.

Sivrikaya O., Yavascan S., Cecen E, 2014. Effects of ground granulated blast- furnace slag on the index and 
compaction parameters of clayey soils. Acta Geotechnica. 1927.

Tanyıldızı M.M, 2010. AASHTO metodunda rijit üstyapı beton kaplama kalınlığına etki eden parametrelerin irdelenmesi, Frrat Üniversitesi Fen Bilimleri Enstitüsü Yüksek Lisans Tezi.

Tokyay M., Erdoğdu K, 2002. Cüruflar ve cüruflu çimentolar, Türkiye Çimento Müstahsilleri Birliği, Ankara.
TS 1900-1, 2006. İnşaat mühendisliğinde zemin laboratuvar deneyleri-Türk Standartları Enstitüsü, Ankara.

Tunç A, 2001. Yol malzemeleri ve uygulamaları. Türkiye.

Yılmaz Y, 2013. Beton endüstrisinde sürdürülebilir üretim. Beton 2013 Kongresi Bildirileri, Cilt1: 145-155, İstanbul.

Yılmaz.I, Yıldıran M., Keskin İ. (2017), Zemin Mekaniği Laboratuvar Deneyleri ve Çözümlü Problemler, Seçkin Kitabevi Ankara. 